\title{
Genetic variability among three Egyptian isolates of Heterorhabditis indica using a new marker technique (SCOT)
}

\author{
Amany M. Abd El Azim and Etr H. K. Khashaba* (1)
}

\begin{abstract}
Background: Entomopathogenic nematodes (EPNs) are a group of nematode families, have the ability to search for their hosts, and are considered as promising biological control candidates for insect pests, providing protection to non-target organisms and the environment.

Results: This study was conducted to isolate indigenous EPN isolates from Egyptian agricultural soils for further use in biological control programs and study their genetic polymorphism among the previously isolated isolates under accession no. MH553167 and MK300683 and the new isolate (MH496627), using the start codon targeted (SCoT) marker. One out of 15 soil samples obtained from a banana cultivated field was positive for the presence of EPNs, using the Galleria baiting method. Morphological analysis and sequencing of the internal transcribed spacer (ITS) region suggested that the isolate obtained belongs to Heterorhabditis indica. The sequence of the ITS was submitted to the National Center for Biotechnology Information (NCBI) and registered under accession no. MH496627. Ten SCOT primers were used in the study; the polymorphic bands were 68 out of 76 with $89 \%$ as polymorphism percentage. The highest numbers of bands were 10 bands generated by SCOT 1 and SCOT 18 while SCOT 48 and SCOT 60 recorded the lowest band number (5 bands).
\end{abstract}

Conclusions: The present study is considered as a preliminary study to demonstrate the effectiveness of the SCoT marker for the first time in assessing genetic relationships in EPNs.

Keywords: Entomopathogenic nematodes, Start codon targeted (SCOT) marker, Genetic polymorphism, Heterorhabditis indica

\section{Background}

Entomopathogenic nematodes (EPNs) (Steinernematidae and Heterorhabditidae) are considered being promising agents, environmentally friendly that can be used in modern agricultural strategies aiming to control insect pests (de Brida et al. 2017). Only the infective third-stage juveniles (IJ) of EPNs are found free living in soils under different ecological conditions and different kinds of habitats and are known as non-feeding stages (Hominick et al. 1996).

Heterorhabditis indica is a heat-tolerant nematode sp. that works best against many insect pests when the

\footnotetext{
* Correspondence: ater_hk@yahoo.com

Plant Protection Research Institute, Agriculture Research Center, Giza, Egypt
}

temperature is between 25 and $29^{\circ} \mathrm{C}$ and can be used as a biological control agent with great potential. Furthermore, indigenous nematodes are more preferred because they have no risks to Egyptian fauna and flora, and they are probably more adaptive (Shehata et al. 2019).

To study the genetic diversity, molecular markers used mainly reveal naturally occurring polymorphisms at the DNA level which makes it a powerful method to evaluate the efficacy of different factors on genetic diversity and population structure (Abd ElAzim et al. 2019). DNA markers are numerous and distinct and are common throughout the genome. They are highly polymorphic and stable and allow the identification of organisms at each stage of growth (Agarwal et al. 2008).

\section{Springer Open}

(อ) The Author(s). 2021 Open Access This article is licensed under a Creative Commons Attribution 4.0 International License, which permits use, sharing, adaptation, distribution and reproduction in any medium or format, as long as you give appropriate credit to the original author(s) and the source, provide a link to the Creative Commons licence, and indicate if changes were made. The images or other third party material in this article are included in the article's Creative Commons licence, unless indicated otherwise in a credit line to the material. If material is not included in the article's Creative Commons licence and your intended use is not permitted by statutory regulation or exceeds the permitted use, you will need to obtain permission directly from the copyright holder. To view a copy of this licence, visit http://creativecommons.org/licenses/by/4.0/. 
Amplified fragment length polymorphism (AFLP), simple sequence repeats (SSR), inter-simple sequence repeats (ISSR), single-strand conformation polymorphism (SSCP), target region amplified polymorphism (TRAP), and sequence-related amplified polymorphism (SRAP) are strongly polymorphic and constant and have been widely used in molecular taxonomy, gene cloning, phylogeny, and genetic mapping (Zhao et al. 2009).

Collard and Mackill (2009) developed a simple novel DNA marker technique, namely start codon targeted (SCoT) polymorphism. SCoT marker analyses are dominant and reproducible markers. This technique was constructed from the conserved region surrounding the translation initiation codon (ATG) based on the design of a single primer and was well characterized in various studies examining the genetic relationships in various species (Amirmoradi et al. 2012). Using agarose gels and staining, amplification products can be easily imaged by ordinary gel electrophoresis, making this procedure more applicable to the massive plant research with standard equipment.

The present study aimed to describe the assessment of the molecular taxonomy and genetic relationships among indigenous EPN isolates belonging to Heterorhabditis indica recovered from three different Egyptian governorates using SCoT markers.

\section{Methods}

\section{Soil sampling}

Fifteen soil samples were collected from banana fields in Port Said Governorate, Egypt (30 $54^{\prime} 29.85^{\prime \prime}$ N, $32^{\circ} 10^{\prime}$ $13.98^{\prime \prime} \mathrm{E}$ ), in 2018. Two hundred fifty grams of the subsamples was placed into a plastic container and transferred to the laboratory for further processing. The soil samples were processed by the insect-baiting G. mellonella (Galleria trap) method (Bedding and Akhurst 1975). Four last instar larvae of G. mellonella were placed inside perforated 250 -g plastic boxes, filled with soil, which were then embedded in the soil sample. Soil samples were stored at $25^{\circ} \mathrm{C}$ and examined every 4 days for dead G. mellonella. The larvae showing symptoms of EPNs' infection were removed. The dead G. mellonella larvae were transferred to white traps (White 1927), and infective juveniles (IJs) collected during the following days were stored at $16^{\circ} \mathrm{C}$ in distilled water.

\section{Nematode identification}

According to the method of Kary et al. (2009), nematode DNA was extracted from IJs, by crushing in $30 \mu \mathrm{l} 1 \times$ PCR buffer and then transferred to a pre-cooled sterilized 1-ml tube containing $15 \mu \mathrm{l}$ of the same buffer. The tubes were incubated at $-70^{\circ} \mathrm{C}$ for $15 \mathrm{~min}$ and thawed at $60{ }^{\circ} \mathrm{C}$ then inoculated with $5 \mu \mathrm{l} \mathrm{of} 60 \mu \mathrm{g} \mathrm{ml}^{-1}$ proteinase $\mathrm{K}$. Then, they were incubated for $2 \mathrm{~h}$ at $65{ }^{\circ} \mathrm{C}$, and after that, they were heated at $95{ }^{\circ} \mathrm{C}$ for $10 \mathrm{~min}$, followed by centrifugation at $15.000 \mathrm{rpm}$ for $10 \mathrm{~min}$ and then the supernatant containing DNA was collected and stored at $-70^{\circ} \mathrm{C}$ until use.

Primers specific to the internal transcribed spacer (ITS) regions of the rDNA region were designed as follows: forward primer TW81 (5-GTTTCC GTA GGT GAA CCT GC-3) and reverse primer AB28 (5-ATA TGC TTA AGT TCAGCG GGT-3) (Joyce et al. 1994). PCR conditions included the initial denaturation at $94^{\circ} \mathrm{C}$ for $5 \mathrm{~min}$, followed by 35 cycles at $94^{\circ} \mathrm{C}$ for $1 \mathrm{~min}, 55^{\circ} \mathrm{C}$ for $1 \mathrm{~min} 30 \mathrm{~s}$, and $72^{\circ} \mathrm{C}$ for $2 \mathrm{~min}$, followed by a final extension at $72{ }^{\circ} \mathrm{C}$ for $7 \mathrm{~min}$. The PCR products were analyzed by agarose gel buffer. The PCR products were purified using the Wizard ${ }^{\circ}$ SV Gel and PCR Clean-Up System Kit (Promega), following the manufacturer's instructions. PCR products were sequenced in both directions by the Macrogen Inc. service, South Korea.

The identity of the sequence was confirmed by a BLAST (Basic Local Alignment Search Tool) search at NCBI then was submitted and located at the NCBI database with the accession number.

\section{Morphological characterization using light microscope}

For light microscopy (LM), the nematodes were stained with acid fuchsin according to Bahgat et al. (2018) then using Olympus CX31 photomicroscope with the XCAM family for photomicrographs of the samples.

\section{SCoT analysis}

A total of 10 SCoT primers developed by Collard and Mackill (2009) were selected for the current study (Table 1). Each 20- $\mu \mathrm{l}$ amplification reaction consisted of $1 \mu \mathrm{l}(100 \mathrm{ng})$ template DNA, $10 \mu \mathrm{l}$ Master Mix (Bioline, GmbH, Germany), $1 \mu \mathrm{l} 25$ pmol primer, and continued with distilled sterilized water. Amplification was performed in a programmed Biometra thermal cycler (vers.1.12tp, 2004) using the following program: $94^{\circ} \mathrm{C}$ for $3 \mathrm{~min} ; 35$ cycles of $94^{\circ} \mathrm{C}$ for $1 \mathrm{~min}, 50^{\circ} \mathrm{C}$ for $1 \mathrm{~min}$, and $72^{\circ} \mathrm{C}$ for $1 \mathrm{~min}$; and a final

Table 1 Names and sequences of SCOT primers and GC\%

\begin{tabular}{lll}
\hline Primers & Sequences & GC\% \\
\hline SCOT 1 & CAACAATGGCTACCACCA & 50 \\
SCOT 4 & CAACAATGGCTACCACCT & 50 \\
SCOT 7 & CAACAATGGCTACCACGG & 56 \\
SCOT 18 & ACCATGGCTACCACCGCC & 67 \\
SCOT 21 & ACGACATGGCGACCCACA & 61 \\
SCOT 36 & GCAACAATGGCTACCACC & 56 \\
SCOT 48 & ACAATGGCTACCACTGGC & 56 \\
SCOT 55 & ACAATGGCTACCACTACC & 50 \\
SCOT 58 & ACAATGGCTACCACTAGG & 50 \\
SCOT 60 & ACAATGGCTACCACCACA & 50 \\
\hline
\end{tabular}


extension at $72^{\circ} \mathrm{C}$ for $5 \mathrm{~min}$. The amplification products were analyzed by electrophoresis in $1.3 \%$ agarose in TAE buffer, stained by ethidium bromide, and photographed under UV light. The sequence of the tested primers is listed (Table 1).

\section{Band scoring and cluster analysis}

The Gel Doc 2000 Bio-Rad system was used for SCoT gel image scanning, and the One Software v 4.0.1 (BioRad Laboratories, Hercules, Co., USA) was used for analyses with quantity. To measure the pairwise differences matrix and plot the dendrogram among the $3 \mathrm{H}$. indica species, the Systat ver. 7 computer programs were used. Cluster analysis on the basis of similarity matrices obtained the arithmetic average (UPGMA) to estimate the dendrogram using the unweighted pair group method.

\section{Results}

From a banana field in the Governorate of Port Said, Egypt, 15 soil samples from sandy clay loam soil type were collected; only one soil sample (7\%) was positive for the occurrence of heterorhabditid nematodes which was assured by the death morphological markers of Galleria larval as brown/black in color. The temperatures of all the collecting points were reported as $25^{\circ} \mathrm{C}$ which affect the occurrence of EPN.

\section{Molecular and phylogenetic analyses based on ITS sequences} For identifying the EPN isolate on the species level, the PCR was amplified using ITS primers, producing PCR product of approximately 500 bp containing ITS1-5.8SITS2 sequences and was identified using BLAST compared to other described species available in GenBank with accession no., and the isolate was classified as Heterorhabditis indica in Fig. 1 and Table 2. The results in Table 2 showed the accession no. of $H$. indica nematode isolates collected from olives and mango fields at Ismailia Governorate and Aborawash, Giza Governorate, Egypt.

\section{Morphological analysis}

Morphology analysis (Fig. 2) of the isolate MH496627 showed the feature characteristic of $H$. indica (infective juvenile tail with dorsal constriction, male robust and curved spicules with a prominent rostrum, pointed female tail, and tail with a short hyaline layer in the sheath).

\section{Polymorphisms detected by SCoT markers}

In the present study, a total of 10 primers were evaluated for amplification among $3 \mathrm{H}$. indica species (ERSAG, ERSAG2, and H. indica Aborawash). Seventysix amplified bands ranged from 200 to 1500 bp were generated by using 10 different primer pairs of SCoT marker; 68 bands were polymorphic. The number of the polymorphic bands ranged from 4 for SCoT 60 to 10 for SCoT 10 with the polymorphism percentage of each primer varied from 75 to $100 \%$ with a total average of $89 \%$. The total number of scored bands varied from 5 for SCoT 48 and SCoT 60 to 10 for SCoT 18 and SCoT 1; the highest number of bands were 10 bands that generated by SCoT 1 primer followed by SCoT 55 (9 bands) while SCoT 60 recorded the lowest band number (4 bands) (Fig. 3 and Table 3).

\section{Relationship between the three Heterorhabditis indica isolates based on SCOT primers}

Obtained data from SCoT primers was used to calculate the phylogenetic relationship among the 3 isolates. The cluster dendrogram showed 2 major clusters. The first cluster was divided into 2 branches; the first one had ERSAG, and the second had ERSAG2 isolate. The second cluster had H. indica Aborawash isolates (Fig. 4).

\section{Discussion}

During the survey in the banana field, one positive EPN isolate was recovered from 15 soil samples collected from different locations throughout the field. The isolate of Heterorhabditis was identified and characterized, using a combination of morphological and molecular

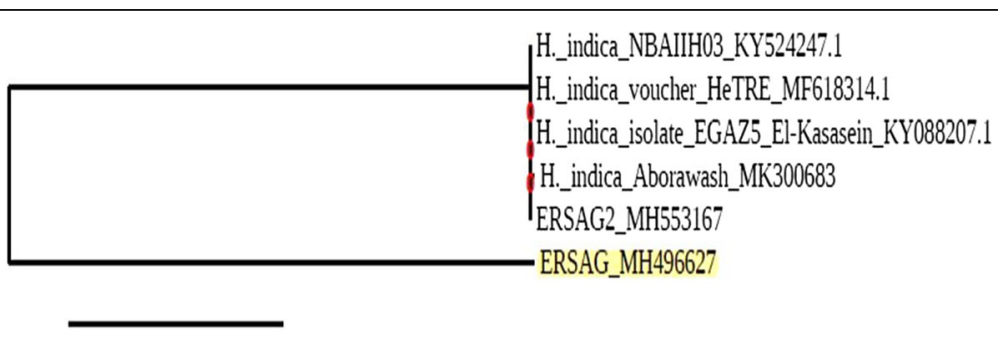

0.2

Fig. 1 Maximum likelihood ITS phylogenetic trees of Heterorhabditis indica species using ITS sequence. Based on nucleotide sequences of $H$. indica (ERSAG, H. indica Aborawash, and ERSAG2) and reference strains (alignment length approximately 700 bp using phylo_tree analysis (phylogeny.fr. program)) 
Table 2 Gene bank accession numbers for ITS1-5.8S-ITS2 sequences and the result of their BLAST against the Nucleotide collection (nt) database of the NCBI website

\begin{tabular}{llll}
\hline Isolate & Accession no. & Species & Habitat \\
\hline ERSAG & MH496627 & Heterorhabditis indica & Banana field \\
ERSAG2 & MH553167 & Heterorhabditis indica & Olive field \\
H. indica Aborawash & MK300683 & Heterorhabditis indica & Mango field \\
\hline
\end{tabular}

techniques. Molecular identifications based on sequences of the ITS region were supported by morphological observations. According to the results obtained, the isolate was $H$. indica.

The occurrence of EPNs in the study area was relatively high $(7 \%)$. The recovery rate for EPNs at this region was expected to be high due to several factors, as the nature of the soil sample is sandy clay loam and the temperature ranging from 23 to $25^{\circ} \mathrm{C}$. This agrees with the findings of Valadas et al. (2013) and Khashaba et al. (2020); also, the sample size increase the probability of positive samples.

The phylogenetic tree based on ITS sequence showed that $H$. indica Aborawash and ERSAG2 belong to the same clade with other $H$. indica species, while the isolate ERSAG in the other clade; this might be due to the geographical difference as Dolgin et al. (2008) called "latitudinal clades."

The genetic characteristics of a species are affected primarily by various ecological and biological traits, modes of reproduction, and breeding. For reconstructing the phylogeny of the EPNs, many molecular techniques have been used, for instance, random amplified polymorphic
DNA (RAPD), restriction fragment length polymorphisms (RFLP), and more recently DNA sequencing, and mitochondrial genes (ND4), simple sequence repeats (SSR), and sequence-related amplified polymorphism (SRAP) have been the most extensively applied (Padmanaban et al. 2014; Abd Elazim et al. 2019).

The SCoT marker systems are proved to be an efficient and inexpensive way to provide molecular data to assess genetic diversity, and it has been used successfully to determine genetic relationships for many plants as reported by Bhattacharyya et al. (2013), but there are no studies being applied about the application of SCoT marker to assess the genetic diversity among entomopathogenic nematode species.

Abu Almaaty (2020) evaluated the genetic variability among 3 gastropod species, using $10 \mathrm{SCoT}$ primers, produced 115 amplicons; their size ranged from 120 to $1500 \mathrm{bp}$ and revealed that the percentage of polymorphism ranged from 20 to $78 \%$. Reporting from all the gained data, it is evident that molecular detection of $\mathrm{SCoT}$ is a suitable tool in assessing genetic variations and relationships among gastropod species. Bhawna et al. (2017) used 20 SCoT markers for
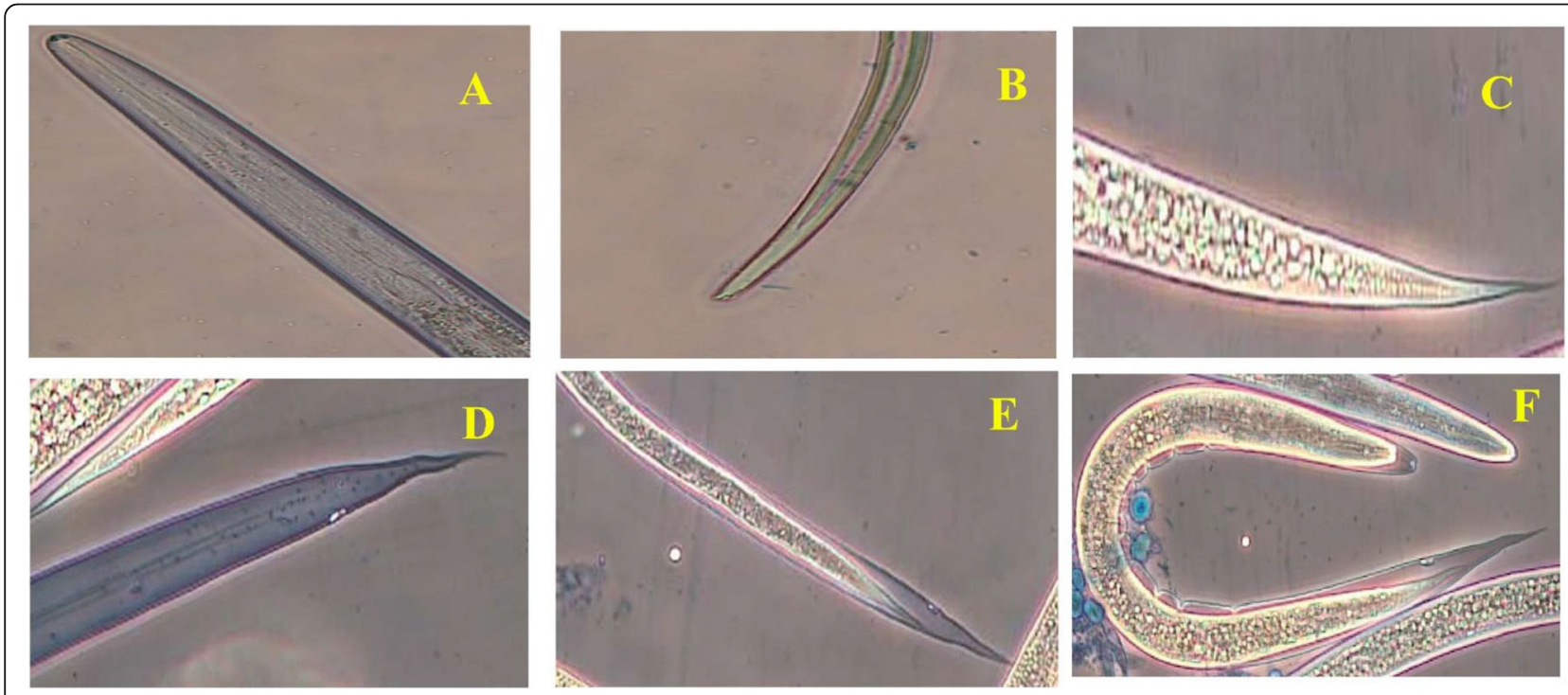

Fig. 2 a Head area exaggerating the mouth and distinct lips of an adult. b Male tail end. c Pointed female tail. d Tail with a dorsal constriction. e, f Tail with a hyaline layer in the sheath 


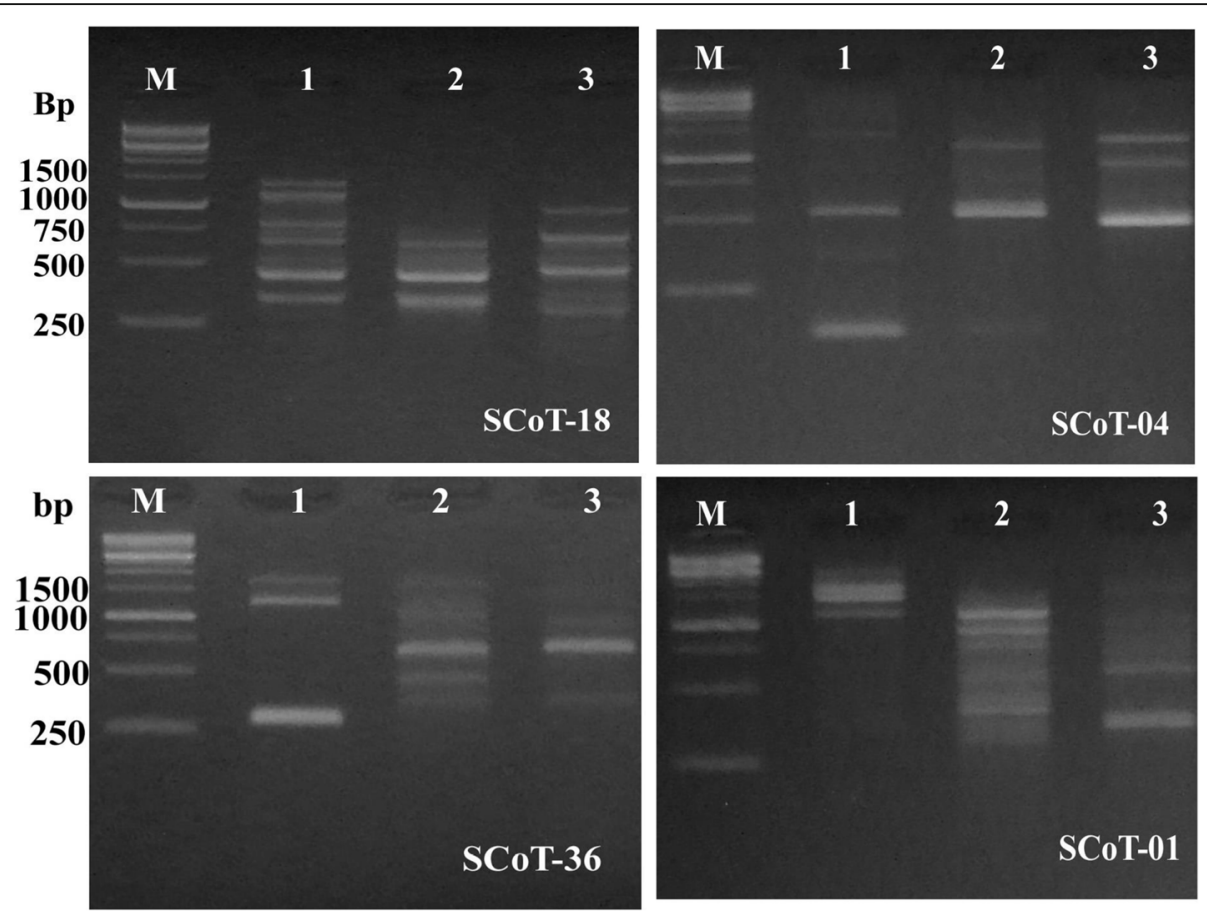

Fig. 3 Genetic polymorphism among the three isolates that belong to the family Heterorhabditis indica as revealed by the SCoT analysis. M, 1 kbp plus DNA ladder; 1-3, the nematode isolates (1, ERSAG; 2, H. indica Aborawash; 3, ERSAG2)

studying the genetic diversity analysis, gene flow, and population structure in the 39 bottle gourd germplasm collected from different regions of India, and the polymorphism percentage was 82.61. From the obtained results, it could be concluded that SCoT markers are promising markers in research for diversity analysis and to target genes easily for the breeder, geneticist, and evolutionists. Also, Satya et al. (2015) used 24 (SCoT) markers to assess the genetic diversity and population structure of indigenous, introduced, and domesticated ramie (Boehmeria nivea $\mathrm{L}$.
Gaudich.), producing 136 amplicons with $87.5 \%$ polymorphism and concluded that the SCoT technique would be useful for further studies in population genetics, conservation genetics, and cultivar improvement.

Therefore, the SCoT marker used in this study was found to be useful and effective for estimating the genetic relationships among indigenous EPNs belonging to $H$. indica species and could be assessed on a wide range of applications in EPNs for evaluating the genetic polymorphism.

Table 3 Total number of scorable bands, polymorphism percentage, and band size of SCoT markers obtained by 10 primers

\begin{tabular}{lllll}
\hline Primers & Total scorable bands & Polymorphic bands & Polymorphism \% & Band size range \\
\hline SCOT 7 & 8 & 6 & 75 & $350-1500$ \\
SCOT 21 & 7 & 6 & 85.7 & $200-1500$ \\
SCOT 18 & 10 & 7 & 70 & $250-1500$ \\
SCOT 55 & 9 & 9 & 100 & $300-1200$ \\
SCOT 58 & 7 & 7 & 100 & $300-1000$ \\
SCOT 48 & 5 & 5 & 100 & $600-1500$ \\
SCOT 60 & 5 & 4 & 80 & $400-1200$ \\
SCOT 36 & 8 & 8 & 100 & $300-1500$ \\
SCOT 1 & 10 & 10 & 100 & $300-1500$ \\
SCOT 4 & 7 & 6 & 85.7 & $200-1500$ \\
Total & 76 & 68 & 89 & \\
\hline
\end{tabular}




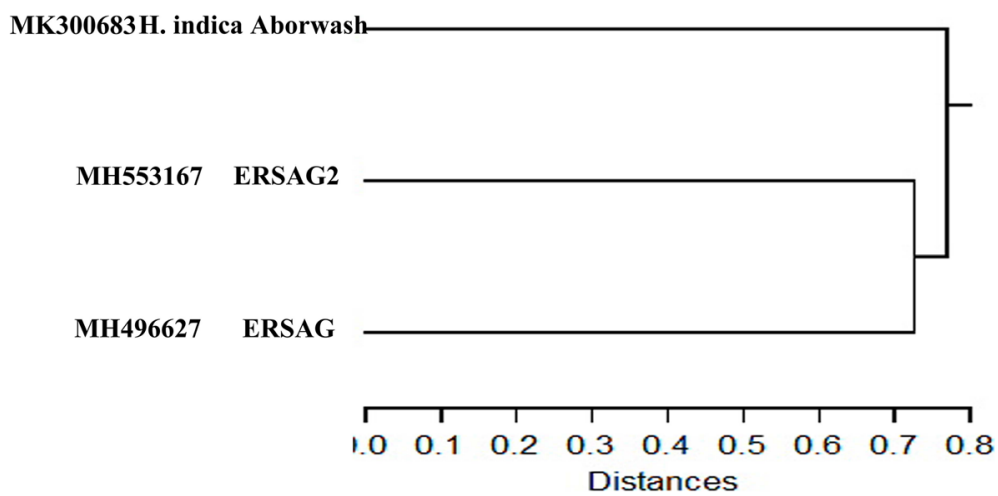

Fig. 4 Phylogenetic tree of the three Heterorhabditis indica isolates based on SCOT markers with the accession numbers of the isolates

\section{Conclusion}

It was concluded that the SCoT marker was successfully used as molecular markers for estimating the genetic polymorphism and phylogenetic relationships among $3 \mathrm{H}$. indica isolates isolated from Egyptian soil at different locations, which might help in biological control programs.

\section{Abbreviations}

RAPD: Random amplified polymorphic DNA; RFLP: Restriction fragment length polymorphisms; ND4: Mitochondrial genes; SSR: Simple sequence repeats; SRAP: Sequence-related amplified polymorphism;

EPN: Entomopathogenic nematodes; SCOT: Start codon targeted; ITS: Internal transcribed spacer region; NCBI: National Center for Biotechnology Information

\section{Acknowledgements}

We would like to thank Prof. Dr. Reda E. Moghaieb (Genetics Department, Faculty of Agriculture, Cairo University, Egypt) for helping in the critical reading of the manuscript.

\section{Authors' contributions}

E. H. K. participated in the experimental design and practical work and coordinated the manuscript writing. A.M.A.A. participated in the experimental design, practical work, and manuscript writing. All authors read and approved the final manuscript.

\section{Funding}

Not applicable

\section{Availability of data and materials}

All datasets are presented in the main manuscript.

\section{Declarations}

Ethics approval and consent to participate

Not applicable

\section{Consent for publication}

Not applicable

\section{Competing interests}

The authors declare that they have no competing interests.
Received: 16 January 2021 Accepted: 13 April 2021

Published online: 26 April 2021

\section{References}

Abd ElAzim AM, Khashaba EHK, Ibrahim SAM (2019) Genetic polymorphism among seven entomopathogenic nematode species (Steinernematidae) revealed by RAPD and SRAP analyses. Egyp J Biol Pest Control 29(1):17. https://doi.org/10.1186/s41938-019-0114-z

Abu Almaaty AH (2020) Potential of start codon targeted (SCOT) markers and SDS-PAGE to estimate genetic diversity and relationships among three gastropods species from the Mediterranean Sea, Port Said, Egypt. Egypt J Aquatic Biol Fish 24(7):133-143. https://doi.org/10.21608/ejabf.2020.118135

Agarwal M, Shrivastava N, Padh H (2008) Advances in molecular marker techniques and their applications in plant sciences. Plant Cell Rep 27(4):617631. https://doi.org/10.1007/s00299-008-0507-z

Amirmoradi B, Talebi R, Karami E (2012) Comparison of genetic variation and differentiation among annual Cicer species using start codon targeted (SCOT) polymorphism, DAMD-PCR, and ISSR markers. Plant Syst Evol 298(9):16791688. https://doi.org/10.1007/s00606-012-0669-6

Bahgat DM, Mossalem HS, Al-Sayed E, Eldahshan OA, Singab Ael NB, Abu El Einin HM (2018) Influence of saponin fraction from Albizia anthelmintica on Biomphalaria alexandrina snail; the intermediate host of Schistosoma mansoni in Egypt. Egypt J Aquatic Biol Fish 22(5):231-240. https://doi.org/10.21608/eja bf.2018.20446

Bedding RA, Akhurst RJ (1975) A simple technique for the detection of insect parasitic nematodes in soil. Nematologica 21(1):109-110. https://doi.org/10.11 63/187529275X00419

Bhattacharyya P, Kumaria S, Kumar S, Tardon P (2013) Start codon targeted (SCOT) marker reveals genetic diversity of Dendrobium nobil Lindl., an endangered medicinal orchid species. Gene. 529(1):21-26. https://doi.org/1 0.1016/j.gene.2013.07.096

Bhawna AMZ, Arya L, Verma M (2017) Use of SCOT markers to assess the gene flow and population structure among two different populations of bottle gourd. Plant Gene 9:80-86. https://doi.org/10.1016/j.plgene.2016.09.001

Collard B, Mackill D (2009) Conserved DNA-derived polymorphism (CDDP): a simple and novel method for generating DNA markers in plants. Plant Mol Biol Report 27(4):558

de Brida AL, Rosa JMO, de Oliveira CMG, de Castro BMC, Zanuncio JES, Cola J, Leite LG, Wilcken SRS (2017) Entomopathogenic nematodes in agricultural areas in Brazil. Sci Rep 7:45254. https://doi.org/10.1038/srep45254

Dolgin ES, Félix MA, Cutter AD (2008) Hakuna Nematoda: genetic and phenotypic diversity in African isolates of Caenorhabditis elegans and C. briggsae. Heredity 100(3):304-315. https://doi.org/10.1038/sj.hdy.6801079

Hominick WM, Reid AP, Bohan DA, Briscoe BR (1996) Entomopathogenic nematodes: biodiversity, geographical distribution and the convention on biological diversity. Biocontrol Sci Tech 6(3):317-331. https://doi.org/10.1080/ 09583159631307

Joyce SA, Burnell AM, Powers TO (1994) Characterization of Heterorhabditis isolates by PCR amplification of segments of mtDNA and rDNA genes. J Nematol 26(3):260-270 
Kary NE, Niknam G, Griffin CT, Mohammadi SA, Moghaddam MA (2009) Survey of entomopathogenic nematodes of the families Steinernematidae and Heterorhabditidae (Nematoda: Rhabditida) in the north-west of Iran. Nematol 11(1):107-116. https://doi.org/10.1163/156854108X398453

Khashaba EHK, Moghaieb REA, Abd El Azim AM, Ibrahim SAM (2020) Isolation, identification of entomopathogenic nematodes, and preliminary study of their virulence against the great wax moth, Galleria mellonella $\mathrm{L}$. (Lepidoptera: Pyralidae). Egyp J Biol Pest Control 30:55

Padmanaban K, Karthik RR, Razia M, Chellapandi P, Sivaramakrishnan S (2014) Genetic diversity of entomopathogenic nematodes in non-agricultural ecosystem revealed with PCR-RAPD markers. Int J Nematol 24(2):1-8

Satya P, Karan M, Sourav J, Sabyasachi M, Ak S, Karmakar PG, Ray DP (2015) Start codon targeted (SCOT) polymorphism reveals genetic diversity in wild and domesticated populations of ramie (Boehmeria nivea L. Gaudich.), a premium textile fiber producing species. Meta Gene 3(C):62-70. https://doi.org/10.101 6/j.mgene.2015.01.003

Shehata IE, Hammam MMA, El-Borai FE, Duncan LW, Abd-Elgawad MMM (2019) Comparison of virulence, reproductive potential, and persistence among local Heterorhabditis indica populations for the control of Temnorhynchus baal (Reiche \&Saulcy) (Coleoptera: Scarabaeidae) in Egypt. Egyp J Biol Pest Control 29(1):32. https://doi.org/10.1186/s41938-019-0137-5

Valadas V, Laranjo M, Mota M, Oliveira S (2013) A survey of entomopathogenic nematode species in continental Portugal. J Helminthol:1-15

White GF (1927) A method for obtaining infective nematode larvae from cultures. Science 66(1709):302-303. https://doi.org/10.1126/science.66.1 709.302-a

Zhao GH, Li J, Zou FC, Mo XH, Yuan ZG, Lin RQ, Weng YB, Zhu XQ (2009) ISSR, an effective molecular approach for studying genetic variability among Schistosoma japonicum isolates from different provinces in mainland China. Infect Genet Evol 9(5):903-907. https://doi.org/10.1016/j.meegid.2009.06.006

\section{Publisher's Note}

Springer Nature remains neutral with regard to jurisdictional claims in published maps and institutional affiliations.

\section{Submit your manuscript to a SpringerOpen ${ }^{\circ}$ journal and benefit from:}

- Convenient online submission

- Rigorous peer review

- Open access: articles freely available online

High visibility within the field

- Retaining the copyright to your article

Submit your next manuscript at $\boldsymbol{\nabla}$ springeropen.com 